\title{
Design and Implement of Dual-axis Solar Tracker in Comparison to Fixed Panel System
}

\author{
R. Saha, R. Bhattacharjee, R. Ali, Shubham, K. Chakraborty, M.G. Choudhury, S. Paul* \\ Advanced Materials Research and Energy Application Laboratory (AMREAL), Department of Energy Engineering, \\ North-Eastern Hill University, Shillong 793022, India
}

(Received 10 January 2021; revised manuscript received 13 June 2021; published online 25 June 2021)

\begin{abstract}
Solar energy is one of the most effective resources because of its cheap source and its reliability to sustain. The best way to attain the maximum possible efficiency from solar panels is to use tracking devices. Solar tracking will contribute significantly to increasing the efficiency of energy collection from the PV panels. Trackers can either be the single- or dual-axis. In this work, we have presented the designing and performance analysis of the dual-axis solar tracking system in comparison to the fixed panel system. We have determined the output power generated by a dual-axis solar tracking system is more than the fixed panel system. The outcome of the dual-axis solar tracking system has been analyzed and compared with the fixed panel system has been highlighted and it has shown better performance in terms of voltage, current, power and battery charging capabilities. Dual-axis trackers give more energy as it tracks sunlight in both the direction. Hence it is more efficient than fixed panel.
\end{abstract}

Keywords: Solar energy, Dual-axis solar tracking system, Fixed panel system, Arduino Nano, Lightdependent sensors (LDRs).

\section{INTRODUCTION}

A solar tracker is a tool that can be used for arranging a solar photovoltaic panel or to direct the solar reflector towards the sun. A solar tracker converts the solar radiation into electrical energy. Despite their increased direct exposure to solar rays, trackers produce more power than their stationary counterparts. This increase is estimated to be as much as $10-40 \%$ depending on the geographic location of the tracking system [1]. Solar monitoring is believed to contribute to expanding the proficiency of sun's vitality diversity from the sunlight-based board control. Many researchers had proposed different methods for designing of a solar tracking system that allows for orienting daylighting reflector by using solar photovoltaic panel or concentrating solar reflector or lens to follow the path of the sun and produce more power as it absorbs more sunlight [2]. Single-axis trackers rotate on one axis usually east-west direction moving back and forth in a single direction. Single-axis trackers include lower cost, higher reliability, and higher lifespan. The dual-axis compared to single-axis captures the solar energy more productively by rotating in both the directions, i.e., horizontal and vertical directions. Fixed panel solar tracker in comparison with a moveable panel solar tracker, the latter is kept under the best possible distance for all positions of the Sun, as the sun's light falls close to the geometric normal incidence angle on it [3]. There was a report on fabrication and installation of a dual-axis solar tracking controller mount with a solar panel in which rays from the sun fall perpendicularly unto the solar panels to maximize the capture of the rays by pointing the sun and following its path [4]. Moreover, a sun tracking system mounted with a solar dish based on computer picture processing of bar shadow with two-axis degree freedoms was reported by the research team. This sys- tem was found to be independent of the geographical location of the solar dish and also of its periodical alignments such as daily or monthly regulations [5]. A comparison of the single-axis solar tracking system and dual-axis tracking system with a fixed mount solar system was compared and found that the efficiency of dual-axis tracking system is higher than the single-axis tracking system [6]. Akbar et al. reported the design of dual-axis solar tracker using an Advanced Virtual RISC (AVR) microcontroller to track the sun in both azimuth and altitude axes and found that the output power generation efficiency increases by $25-30 \%$ [7]. An improved model of dual-axis solar tracker combining with concentrated solar power and photovoltaic technology was designed by a research team and showed that the tracking system would be cheaper than the other solar panelbased dual-axis tracker [8]. A low-profile tracker comprising of two coplanar and perpendicular linear actuators that are coupled with a single linkage arm and pivots was proposed by Baker et al. and found that the tracker is inherently accurate and utilizes translational motion with no significant change in the shadow footprint [9]. A dual-axis solar programmable logical controller (PLC) based automatic tracking system along with its supervisory and control system was designed and implemented by a research group and the result shows that the electricity generated by the proposed tracking system showed an overall increase of about 8$25 \%$ more than the fix-angle PV system [10].The high penetration of the one-axis and two-axis tracker in large-scale PV power plants is because of the way that sun following frameworks considerably improves the everyday vitality creation of level plate modules. A noble design of a dual-axis solar tracking PV system using four LDR sensors and the simple electronic circuit was proposed by Wang and his team and found that the design system achieved increased energy gain by up to

\footnotetext{
*paulsamrat17@gmail.com

The results were presented at the International Conference on Innovative Research in Renewable Energy Technologies (IRRET-2021)
} 
$28.31 \%$ in a partly cloudy day [11]. Moreover, Sharma et al. fabricated a tracking system set up with a mechanical mechanism to tilt the flat PV panel towards the sun using DC motor and LDR sensor. They found that the energy consumed by the tracking system is very less [12]. Solar monitoring is not a new idea; however, it is an extensively new idea contrasted with PV cells. To achieve this in a genuine circumstance, the photovoltaic panel must move with the sun to keep maintaining this perpendicular angle. A dual-axis solar tracking device was structured utilizing an LDR sensor, DC motors and a microcontroller to make it equipped for the uninterruptible supply of electricity for rural applications [13]. A research team presented a noble design for tracking mechanisms using a three-fold strategy and found that the tracking system shows a power output conversion efficiency of $43.6 \%$ in comparison to fixed-panel [14]. A fixed panel system is less efficient in comparison to a moveable tracking system is the fact it does not rotate as a result at times they are unable to capture the maximum intensity of sunlight. The direction of the sun-powered boards is kept unaltered during the whole year. It is accepted that sunpowered following will contribute altogether to expanding the effectiveness of vitality assortment from the PV panel. A study on the newly designed dual-axis solar tracking system was reported and tested at several locations to track the sun position. This design offers several advantages in addition to its improved efficiency [15]. The designing of a solar tracking system based on a manually controlled hydraulic direction unit is reported, as it could be operated with a circuit that is controlled by micro-controller circuit [16].

In this work, we have presented the designing and performance analysis of the dual-axis solar tracking system in comparison to fixed panel system. We have determined the output power generated by a dual-axis solar tracking system is more than that in the fixed panel system. The outcome of the dual-axis solar tracking system has been analyzed and compared with the fixed panel system has been highlighted and it has shown better performance in terms of voltage, current, power and battery charging capabilities.

\section{DESIGN OF DUAL-AXIS TRACKING SYSTEM AND FIXED PANEL SYSTEM}

The purpose of a solar tracker is to accurately determine the position of the sun. It demonstrates the solar panel that is installed in the system for tracking the maximum solar energy from the sun at all times when the sun is out.The components used for the designing of the solar tracker hardware with the specification is shown in Table 1.

Table 1 - Components used

\begin{tabular}{|l|l|}
\hline $\begin{array}{l}\text { Components } \\
\text { Name }\end{array}$ & Specification \\
\hline Solar Panel & $\begin{array}{l}\text { PV Panel Dimensions: } 67 \mathrm{~cm} \times 55 \mathrm{~cm} \\
\text { PV Panel Ratings: 50 Watt } \\
\text { PV Panel Materials: Polycrystalline }\end{array}$ \\
\hline $\begin{array}{l}\text { Light Dependent } \\
\text { Resistors (LDRs) }\end{array}$ & Light Dependent Resistors: GM 9516 \\
\hline DC Geared motor & Motor: 12 V DC Geared Motor \\
\hline
\end{tabular}

\begin{tabular}{|l|l|}
\hline Arduino NANO & Controller: Arduino Nano \\
\hline Limit Switch & Limit Switch: 5 A-12 V \\
\hline $\begin{array}{l}\text { Solar Charge } \\
\text { Controller }\end{array}$ & Solar Charge Controller: 12 V - 6 A \\
\hline Battery & Battery: 12 V-8 Ah \\
\hline Inverter & $\begin{array}{l}\text { Inverter: 12 V DC to 220 V AC, } \\
\text { Output up to 40 Watts }\end{array}$ \\
\hline $\begin{array}{l}\text { Battery Charge } \\
\text { Indicator }\end{array}$ & $\begin{array}{l}\text { Battery Charge Indicator: Type } \\
\text { Number SAA1501T }\end{array}$ \\
\hline
\end{tabular}

\subsection{Dual-axis Tracking System}

In our solar tracker, solar panels are mounted to follow the path of the sun. Four Light Dependent Resistors (LDRs) were used to track the position of the Sun in the tracking system. A DC geared motor as a low rpm high torque motor has been used in the system to consume less current as compared to other motors. An Arduino NANO microcontroller as an integrated chip was used to execute programs for controlling other devices or machines. In the system, four limit switches were used as safety interlocks controlling machinery as part of a control system. The working of the dual solar tracking system is shown with the help of a block diagram (Fig. 1) and schematic representation of the electrical circuit (Fig. 2).

LDRs pass the signal to micro-controller to track the accurate position of the sun. According to the programming logic, the operation happens and the controller, then sends the signal to the motor driver which rotates the motors. Motor 1 is for daily movement and Motor 2 is for seasonal movement of the panel.

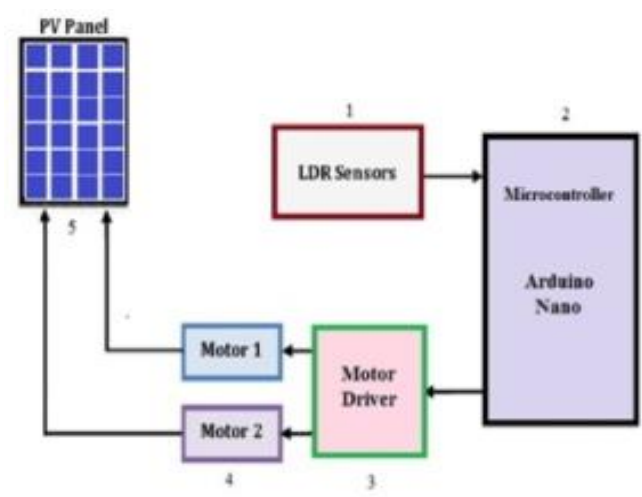

Fig. 1 - Block diagram of the dual-axis solar tracker

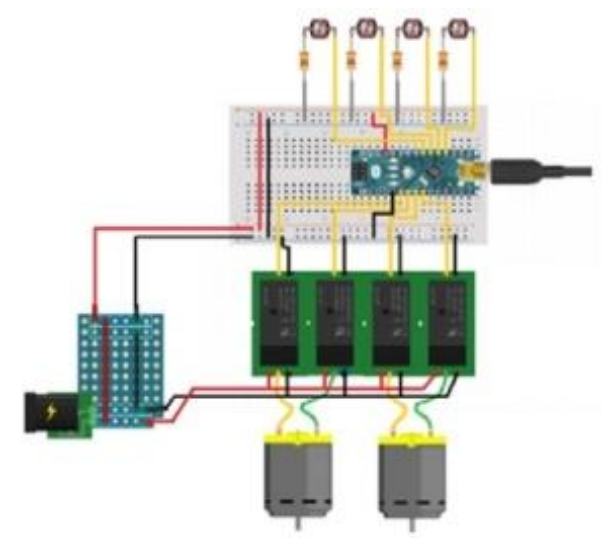

Fig. 2 - Electrical circuit of the dual-axis solar tracker 
As shown in the above circuit diagram, four LDRs were used to track the sun. Among the four LDRs which pair gets more sun intensity that pair of LDRSs passes the signal and Arduino Nano receives the signal as input. Now according to the programming logic operation happen and send an output signal to relay switch as shown in the circuit diagram. The Relay switch then controls the movement of motors. The design models of the dual-axis tracking system and fixed panel system are shown in Fig. 3.

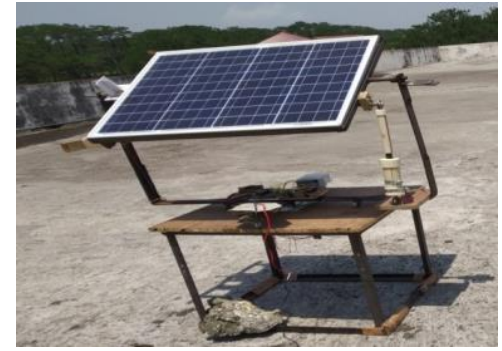

a

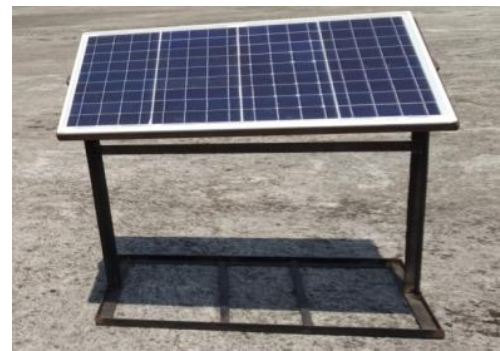

$\mathrm{b}$

Fig. 3 - (a) Dual-axis solar tracking system and (b) fixed panel system

\section{RESULTS AND DISCUSSION}

With the help of $I-V$ characteristics of the solar panel, we can determine out the parameters such as power output, voltage, current and fill factor, respectively. The readings for the above paraments were taken in the school of technology, North-Eastern Hill University, Shillong, Meghalaya. The Power Output readings for different tracking system was taken at intensity of $10.74 \mathrm{~W} / \mathrm{m}^{2}$.

Fig. 4 shows the PV panel's output power curve as a function of voltage ( $P-V$ characteristics) of the fixedpanel and dual-axis model under the radiation level of $10.74 \mathrm{~W} / \mathrm{m}^{2}$. A comparison of measuring the $P-V$ characteristic is made between the fixed-panel and dualaxis model, to demonstrate an appropriate performance of the proposed tracking system. The power output depends on the amount of solar radiation or light intensity falling on the surface of the PV panel. The average value of power of fixed panel is found to be $11.23 \mathrm{~W}$, whereas the average value of power of dualaxis is found to be $27.75 \mathrm{~W}$. The $P-V$ curve is dependent on the voltage, the current, and the power of the PV panel. The power output, at $V_{O C}$ and $I_{S C}$, becomes zero and maximum at a particular point between the points termed as maximum power point. The values of the voltage and current at such points denote the maxi- mum power voltage and the maximum power current $V_{M}$ and $I_{M}$, respectively. From the curve, $V_{M}$ and $I_{M}$ for dual-axis was found to be $16.5 \mathrm{~V}$ and $-1.03 \mathrm{~A}$, for fixedpanel $13 \mathrm{~V}$ and $-1.06 \mathrm{~A}$ respectively. It is observed from the $P-V$ graph, that the PV panel based dual-axis solar tracker shows satisfactory performance and reveals that the higher the solar radiation the better is the output performance. It is seen that the proposed tracking system is able to extract the $P-V$ curve of a PV panel with an acceptable accuracy. The fill factor of our fixed panel solar tracker panel was found to be 0.62 and for dual-axis solar tracker was found to be 0.70 . Hence, we see that a dual-axis solar tracking system shows a higher value of the fill factor in comparison to fixed panel solar tracker.

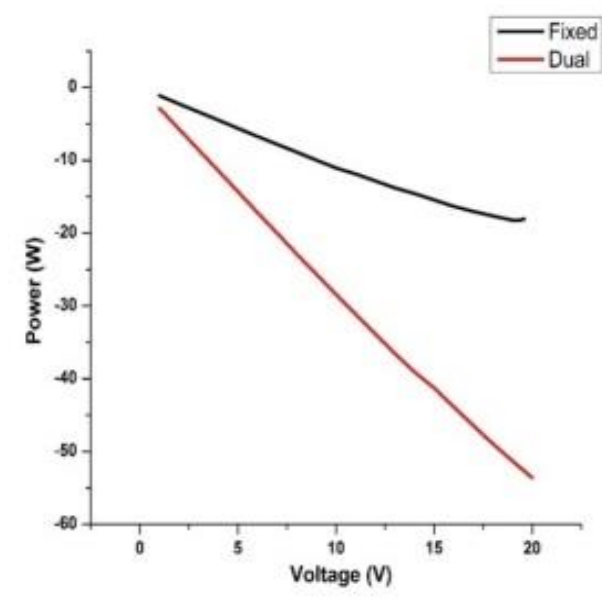

Fig. $4-P-V$ characteristics of fixed panel vs. dual-axis solar tracker at an intensity of $10.74 \mathrm{~W} / \mathrm{m}^{2}$ under direct sunlight

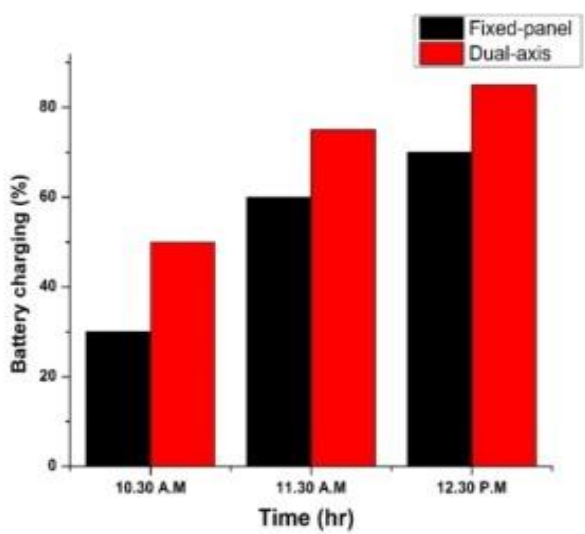

Fig. 5 - Battery charging capacity timing for fixed panel system vs. dual-axis solar tracker

The graph deviates from the ideal $P-V$ characteristics graph because the readings were not taken under ambient conditions. Moreover, there were other factors like the weather was not an ideal one as there was some clouds covering hovering around the sky, as a result of which appropriate amount of light did not get accumulated into the solar panel. This led to some absurd values of voltage and current which resulted in a deviation of our experimentally found $P-V$ characteristics from the ideal $I-V$ characteristics graph.

Fig. 5 shows the graph of the time required to 
charge a $12 \mathrm{~V}, 8 \mathrm{Ah}$ battery by a fixed panel system and dual-axis solar tracking system on. The proposed system efficiency was tested by using the battery as a reference for measuring the amount of energy is discharged and charged from it. The output voltage from the solar panel is higher than the voltage of the battery, to enable charging of the battery. The battery charging capacity of the dual-axis solar tracking system is more than fixed panel system as shown in Fig. 5.

After analyzing from the figure, we observed that, as the battery capacity value of a dual-axis solar tracking system exceeds $50 \%$ it takes more time to charge the battery thereafter. For a dual-axis solar tracking System initially, the battery charges rapidly from 0 $50 \%$ in about an hour. After that, it takes time to charge the battery from $50 \%$ onwards, with approximately 10-20\% increase in charge in every hour. However, for a fixed panel system initially, the battery charges rapidly from $0-30 \%$ in about an hour. After it takes time to charge the battery from $50 \%$ onwards, with approximately $10 \%$ increase in charge in an hour.

\section{CONCLUSIONS}

In this work, we have developed and implemented a dual-axis solar tracking system. We have improved the design characteristics of the dual-axis solar tracking system to improve performance. The main contribution of the dual-axis solar tracking system involves resulting efficient, profitable and clean power production in the future. In this work, we have highlighted that dualaxis solar tracking system is more efficient in terms of the electrical energy output when compared to the fixed solar panel system. We have performed two experiments and find out that the dual-axis solar tracker is more power-efficient and gives better performance in comparison to the fixed panel system.

\section{ACKNOWLEDGEMENTS}

The authors acknowledge SERB, DST, New Delhi (File no-SERB/F/9654/2016-17 and PDF/2016/002390) for the financial support to carry out this work.

\title{
REFERENCES
}

1. A.C. Chhotonand, N.R. Chakraborty, 4th Int. Conf. Adv. Electr. Engin. (ICAEE-2017), 421 (Dhaka: Bangladesh: 2017).

2. F.M. Mustafa, S.A. Ahmed, IARJSET 4 No 11, 11 (2017).

3. T. Tudorache, L. Kreindler, Acta Polytech. Hung. 7 No 1, 23 (2010).

4. N. Barsoum, Intell. Control Autom. 2 No 2, 57 (2011).

5. H. Arbab, B. Jazi, M. Rezagholizadeh, Renew. Energy 34 No 4, 1114 (2009).

6. S. Deepthi, A. Ponni, R. Ranjitha, R. Dhanabal, IJESIT 2 No 2, 425 (2013).

7. H.S. Akbar, A.I. Siddiq, M.W. Aziz, Am. J. Energy Res. 5 No 1, 23 (2017).

8. A.R.M. Siddique, T. Titirsha, S. Sanjidah, F. Afrin, A. Rabbani, IJSER 5, No 3, 582 (2014).

9. L. Barker, M. Neber, H. Lee, Sol. Energy 97, 569 (2013).

10. T. Zhan, W. Lin, M. Tsai, G. Wang, IEEE 37th Annual Computer Software Appl. Conf. (COMPSAC-2013), 276 (Kyoto: Japan: 2013)

11. J-M. Wang, C-L. Lu, Sensors 13 No 3, 3157 (2013).

12. A. Sharma, C. Sharma, Ijest-ng 9, 39 (2017).

13. H.N. Amadi, S. Gutiérrez, J. Electr. Electron. Syst. 7 (2018).

14. Y.S. Rambhowan, V. Oree, Appl. Sol. Energy 50, 74 (2014).

15. Er. Zuhal, E. Balci, J. Energy Syst. 2 No 3, 127 (2018).

16. L. Singh, Jujhar Singh, Am. J. Comp. Sci. Eng. Surv. 4 No 3, 048 (2016).

\section{Розробка та впровадження двовісної системи стеження за сонцем у порівнянні із системою нерухомих панелей}

\author{
R. Saha, R. Bhattacharjee, R. Ali, Shubham, K. Chakraborty, M.G. Choudhury, S. Paul \\ Advanced Materials Research and Energy Application Laboratory (AMREAL), Department of Energy Engineering, \\ North-Eastern Hill University, Shillong 793022, India
}

\begin{abstract}
Сонячна енергія є одним з найефективніших ресурсів через дешевизну джерела та його надійність Найкращим способом досягти максимально можливої ефективності сонячних панелей $е$ використання пристроїв стеження. Системи стеження за сонцем суттево сприятимуть підвищенню ефективності збору енергії від фотоелектричних панелей. Системи стеження можуть бути як одновісними, так і двовісними. У роботі ми представили дизайн та аналіз продуктивності двовісної системи стеження за сонцем у порівнянні із системою нерухомих панелей. Ми визначили, що вихідна потужність, генерована двовісною системою стеження за сонцем, більше, ніж потужність системи нерухомих панелей. Результати роботи двовісної системи стеження за сонщем були проаналізовані порівняно із роботою системи нерухомих панелей і показали кращі характеристики с точки зору напруги, струму, потужності та можливост заряджання акумулятора. Двовісні системи стеження дають більше енергії, оскільки вони відстежують сонячне світло в обох напрямках. Отже, вони є більш ефективним, ніж нерухомі панелі.
\end{abstract}

Ключові слова: Сонячна енергія, Двовісна система стеження за сонцем, Система нерухомих панелей, Arduino Nano, Залежні від світла датчики (LDRs). 